\title{
Long-term prognosis in children with recurrent abdominal pain
}

\author{
M. FJORD CHRISTENSEN and O. MORTENSEN \\ From the University Clinic of Paediatrics, Arhus Municipal Hospital, Denmark
}

\begin{abstract}
Christensen, M. F., and Mortensen, O. (1975). Archives of Disease in Childhood, 50, 110. Long-term prognosis in children with recurrent abdominal pain. The present study is a follow-up of 34 cases admitted to a paediatric department with recurrent abdominal pain (RAP) in 1942 and 1943. 45 persons without a history of RAP were selected at random and included as controls. Using a questionnaire, there was a higher incidence of gastrointestinal symptoms among persons with a history of RAP during childhood than among controls $(P<0.05)$. 18 of the original 34 cases who still had symptoms were re-examined; 11 had a clinical picture consistent with a diagnosis of irritable colon, 5 had a picture compatible with both irritable colon and peptic ulcer/gastritis, and 2 had duodenal ulcer.

Abdominal pains occurred no more frequently among children of parents who had had RAP during childhood than among children of parents without such a history. However, there was a higher incidence of abdominal pain among children of parents who were complaining of abdominal discomfort at the time of the investigation than among children whose parents were without such symptoms $(P<0.005)$.
\end{abstract}

It has been generally held that the prognosis for children with recurrent abdominal pain (RAP) is good, though this point of view is not supported by the few published follow-up studies. Apley (1959) examined 30 persons who had been in hospital as children with RAP 8-20 years earlier. The patients had received no or inadequate treatment. 9 were free from symptoms. In 9 cases the episodes of abdominal pain had ceased only to be replaced by other symptoms, especially headache. In 12 cases abdominal pains persisted, mostly accompanied by 'nervous' complaints. Among 18 controls, one had severe headache, 4 had occasional slight headache, 3 had occasional abdominal discomfort, and one suffered from nervousness.

Apley and Hale (1973) reported a follow-up of 30 persons 10-14 years after they had been referred to a children's hospital on account of RAP and treated with reassurance and explanation. The results were similar to those of the first study except for the following points: the children who responded to treatment recovered more quickly than those described in the first study; relapse did not occur in treated patients; and in the treated group fewer nonabdominal disorders developed.

Received 29 July 1974.
In another noncontrolled follow-up study comprising 116 children with abdominal pains, Dahl and Haahr (1969) reported that $48 \%$ had obtained relief of their symptoms, while $36 \%$ were still suffering from abdominal pains. In $16 \%$ the abdominal symptoms had ceased, but other complaints had appeared. This study was carried out between one and 10 years after discharge from hospital. A fourth study, that of Papatheophilou, Jeavons, and Disney (1972), was incomplete, since information was only obtained from 14 of 100 patients; in these the abdominal pains had disappeared by the age of 11-12 years.

We have carried out a controlled investigation of the long-term prognosis of 34 children with RAP, partly in order to supplement previous studies, and partly for the purpose of elucidating the type of abdominal discomfort in adults with continued symptoms. In addition, there was an opportunity to obtain information about abdominal pains in the original patients' children.

\section{Patients and methods}

From 1 April 1942 to 31 December 1943 a total of 38 children, aged between 2 years 11 months and 13 years, with an average age of 7 years 10 months, were referred to the paediatric department of the Arhus 
Municipal Hospital with RAP. All children were subjected to inpatient hospital evaluation as part of a research project concerning children with RAP. Routine studies included ESR and $\mathrm{Hb}$ concentration, urine analysis, tuberculin test, examination of gastric juice by test meal, barium meal, examination of the stool for blood, and assessment of the intelligence quotient. The 38 children had typical histories of RAP and fulfilled the following diagnostic criteria. They had complained of at least three episodes of abdominal pain in a period longer than 3 months. No organic diseases were found to account for the pain. The type of treatment applied was reassurance based on explanation of the character of the condition.

The follow-up investigation had two purposes. (1) To compare these original 38 patients as adults with controls, and look for possible differences in the frequency of both abdominal and nonabdominal symptoms, in social status and in the frequency of abdominal pains in their offspring. This part of the investigation was based on a questionnaire. (2) To elucidate the type of abdominal discomfort in adults with continued symptoms. This part of the investigation was based on interview and examination.

From 1970 to 1972 , all 38 persons were located through the public registration office. Elaborate questionnaires relating to their social status and health and also to the health of their children were forwarded by mail. Complete answers were received from 20 females and 14 males. The average age of these 34 persons at the time of the follow-up study was 35 years 11 months. Those complaining of persistent abdominal symptoms were contacted by one of the authors (M.F.C.), a detailed interview and thorough clinical examination took place, and relevant information concerning previous hospitalization and examinations in outpatient clinics was provided.

The control material consisted of 59 persons born between 1 January 1930 and 31 December 1940, selected at random on the basis of their registration number in the public registration office in Arhus. They received a similar questionnaire and this was completed by 52 . 7 who appeared to have had abdominal pains as children were excluded. The remaining 45 included 25 males and 20 females with an average age of 36 years 5 months.

A tentative diagnosis of irritable colon was accepted in the presence of colonic pain accompanied by at least one of the following symptoms: periods with constipation and/or diarrhoea, and meteorism, in the absence of other recognized colonic disease. A diagnosis of peptic ulcer/gastritis was accepted when supported by $x$-ray study, or suggested by epigastric pain provoked by hunger, in the absense of other recognized relevant abdominal disorder.

A diagnosis of abdominal pains in children of the original patients and the control subjects was accepted if the children were 3-15 years old, and if the point in the questionnaire asking whether they suffered from abdominal pains was answered in the affirmative. For statistical evaluation the $\chi^{2}$ test was used.

\section{Results}

According to the questionnaire 18 of the original 34 patients, 11 females and 7 males, had suffered from chronic or recurrent abdominal symptoms as adults. In the controls 13 of 45,8 females and 5 males, had also experienced this (Table I). The

\section{TABLE I}

Frequency of abdominal symptoms in adults with and without recurrent abdominal pain in childhood

\begin{tabular}{c|c|c}
\hline & $\begin{array}{c}\text { 34 Adults with } \\
\text { recurrent abdominal } \\
\text { pain in childhood }\end{array}$ & $\begin{array}{c}\text { 45 Adults without } \\
\text { recurrent abdominal } \\
\text { pain in childhood }\end{array}$ \\
\hline $\begin{array}{c}\text { Abdominal } \\
\text { symptoms } \\
\begin{array}{c}\text { No abdominal } \\
\text { symptoms }\end{array}\end{array}$ & 18 & 13 \\
\hline
\end{tabular}

difference is significant $(P<0.05) . \quad 11$ of the 18 persons with continual symptoms had experienced a symptom-free period during adolescence.

A further study of the 18 adults with recurrent or persistent abdominal symptoms showed that 11, 8 females and 3 males, had a clinical picture consistent with the diagnosis of irritable colon. 5, 3 females and 2 males, had a picture compatible with both irritable colon and peptic ulcer/gastritis. The remaining 2 patients, both males, had duodenal ulcer, verified by barium meal (Table II).

Twelve patients had mild symptoms, but 5 had more pronounced discomfort which limited normal activities. One was sufficiently severely affected to have been admitted to hospital on several occasions.

Nongastrointestinal symptoms were also significantly commoner in the original patients than the controls. Among the 34 patients 11 had other complaints, especially headache, often migrainous, back pain, 'bad nerves', or gynaecological symptoms. Among the 45 controls, only 6 had nongastrointestinal symptoms (Table III). The difference is significant $(P<0.05)$.

Social assessment with respect to occupation and marital status showed no difference between the two groups. Neither was there any demonstrable difference in the incidence of abdominal pains among the offspring of these groups $(P>0.05)$ (Table IV). The average age of the original patients' children between 3 and 15 was 8 years 6 months; the corresponding figure for the children of the control subjects was 9 years 4 months.

A total of 86 adults, patients and controls, answered the questionnaire. Of these, $37 \mathrm{had}$ 
Type of abdominal discomfort in 18

\begin{tabular}{|c|c|c|}
\hline Case no. & $\begin{array}{c}\text { Pain } \\
\text { localization }\end{array}$ & $\begin{array}{c}\text { Pain } \\
\text { description }\end{array}$ \\
\hline $\begin{array}{r}5 \\
10\end{array}$ & $\begin{array}{l}\text { Periumbilical } \\
\text { Epigastric }\end{array}$ & $\begin{array}{l}\text { Colicky } \\
\text { Burning, }\end{array}$ \\
\hline 11 & $\begin{array}{l}\text { Epigastric, } \\
\text { periumbilical }\end{array}$ & $\begin{array}{c}\text { Burning, } \\
\text { colicky }\end{array}$ \\
\hline $\begin{array}{l}12 \\
13\end{array}$ & $\begin{array}{l}\text { Periumbilical } \\
\text { Epigastric } \\
\text { left of umbilicus }\end{array}$ & $\begin{array}{l}\text { Colicky } \\
\text { Colicky, } \\
\text { grumbling }\end{array}$ \\
\hline 15 & $\begin{array}{l}\text { Whole abdominal } \\
\text { region }\end{array}$ & Colicky \\
\hline 16 & Periumbilical & Colicky \\
\hline 17 & Periumbilical & $\begin{array}{l}\text { Grumbling, } \\
\text { colicky }\end{array}$ \\
\hline $\begin{array}{l}18 \\
19 \\
20 \\
22\end{array}$ & $\begin{array}{l}\text { Infraumbilical } \\
\text { Epigastric } \\
\text { Periumbilical } \\
\text { Left of umbilicus }\end{array}$ & $\begin{array}{l}\text { Colicky } \\
\text { Burning } \\
\text { Squeezing } \\
\text { Colicky }\end{array}$ \\
\hline $\begin{array}{l}23 \\
24\end{array}$ & $\begin{array}{l}\text { Right epigastric } \\
\text { Epigastric, } \\
\text { periumbilical }\end{array}$ & $\begin{array}{l}\text { Burning } \\
\text { Burning, } \\
\text { colicky }\end{array}$ \\
\hline & $\begin{array}{l}\text { Epigastric } \\
\text { left of umbilicus }\end{array}$ & $\begin{array}{l}\text { Hunger, } \\
\text { colicky }\end{array}$ \\
\hline $\begin{array}{l}26 \\
27\end{array}$ & $\begin{array}{l}\text { Left of umbilicus } \\
\text { Epigastric, } \\
\text { periumbilical }\end{array}$ & $\begin{array}{l}\text { Grumbling } \\
\text { Hunger, } \\
\text { colicky }\end{array}$ \\
\hline 34 & Periumbilical & Colicky \\
\hline \multicolumn{3}{|c|}{$\begin{array}{l}\text { TABLE III } \\
\text { Frequency of nonabdominal symptoms in adults with } \\
\text { and without recurrent abdominal pain in childhood }\end{array}$} \\
\hline & $\begin{array}{l}34 \text { Adults with } \\
\text { recurrent abdominal } \\
\text { pain in childhood }\end{array}$ & $\begin{array}{l}45 \text { Adults without } \\
\text { recurrent abdominal } \\
\text { pain in childhood }\end{array}$ \\
\hline \multirow{2}{*}{$\begin{array}{l}\text { Nonabdominal } \\
\text { symptoms present } \\
\text { Nonabdominal } \\
\text { symptoms absent }\end{array}$} & 11 & 6 \\
\hline & 23 & 39 \\
\hline
\end{tabular}

abdominal complaints and 49 were symptom free. In the children of the former group abdominal

pains occurred definitely more frequently $(P<0.005)$ than in children whose parents were without symptoms (Table V).

\section{Discussion}

Even if the nature of the condition of RAP is not fully understood there seems to be some agreement on the following points. The pain tends to occur in 'sensitive' children (Apley, 1959; Moro, 1913; Stone and Barbero, 1970) when they are exposed to emotional tension (Apley, 1959; British Medical Journal, 1970; Green, 1967; Mac Keith and O'Neill, 1951; Moro, 1913; Singh, Gupta, and Agrawal, 1972; Stone and Barbero, 1970), and in whose

TABLE IV

Abdominal pains in children of adults with and without recurrent abdominal pain in childhood

\begin{tabular}{l|r|r}
\hline & $\begin{array}{c}47 \text { Children of adults with recurrent } \\
\text { abdominal pain in childhood }\end{array}$ & $\begin{array}{r}58 \text { Children of adults without recurrent } \\
\text { abdominal pain in childhood }\end{array}$ \\
\hline $\begin{array}{l}\text { Abdominal pains present } \\
\text { Abdominal pains absent }\end{array}$ & 38 & 7 \\
\hline
\end{tabular}


with recurrent abdominal pain in childhood

\begin{tabular}{|c|c|c|c|c|c|}
\hline $\begin{array}{c}\text { Hunger } \\
\text { provocation }\end{array}$ & $\begin{array}{l}\text { Diarrhoea and/or } \\
\text { constipation }\end{array}$ & Meteorism & $\begin{array}{l}\text { Tender } \\
\text { colon }\end{array}$ & $X$-ray & $\begin{array}{l}\text { Tentative } \\
\text { diagnosis }\end{array}$ \\
\hline $\begin{array}{l}\text { No } \\
\text { No }\end{array}$ & $\begin{array}{l}\text { No } \\
\text { No }\end{array}$ & $\begin{array}{l}\text { Yes } \\
\text { Yes }\end{array}$ & $\begin{array}{l}\text { No } \\
\text { Yes }\end{array}$ & Gastritis & $\begin{array}{l}\text { Irritable colon } \\
\text { Irritable colon, }\end{array}$ \\
\hline Yes & Yes & Yes & Yes & & $\begin{array}{l}\text { Irritable colon, } \\
\text { gastritis/ } \\
\text { peptic ulcer }\end{array}$ \\
\hline $\begin{array}{l}\text { No } \\
\text { No }\end{array}$ & $\begin{array}{l}\text { Yes } \\
\text { Yes }\end{array}$ & $\begin{array}{l}\text { Yes } \\
\text { Yes }\end{array}$ & $\begin{array}{l}\text { Yes } \\
\text { Yes }\end{array}$ & $\begin{array}{l}\text { Barium meal, enema, } \\
\text { and pyelography } \\
\text { negative }\end{array}$ & $\begin{array}{l}\text { Irritable colon } \\
\text { Irritable colon }\end{array}$ \\
\hline No & Yes & Yes & Yes & & Irritable colon \\
\hline No & Yes & Yes & Yes & Barium enema & Irritable colon \\
\hline No & No & Yes & Yes & & Irritable colon \\
\hline $\begin{array}{l}\text { No } \\
\text { Yes } \\
\text { No } \\
\text { No }\end{array}$ & $\begin{array}{l}\text { Yes } \\
\text { No } \\
\text { No } \\
\text { Yes }\end{array}$ & $\begin{array}{l}\text { Yes } \\
\text { Yes } \\
\text { Yes } \\
\text { Yes }\end{array}$ & $\begin{array}{l}\text { Yes } \\
\text { No } \\
\text { Yes } \\
\text { Yes }\end{array}$ & $\begin{array}{l}\text { Duodenal ulcer } \\
\text { Spastic colon with } \\
\text { sigmoidal diverticula }\end{array}$ & $\begin{array}{l}\text { Irritable colon } \\
\text { Duodenal ulcer } \\
\text { Irritable colon } \\
\text { Irritable colon }\end{array}$ \\
\hline $\begin{array}{l}\text { No } \\
\text { Yes }\end{array}$ & $\begin{array}{l}\text { No } \\
\text { Yes }\end{array}$ & $\begin{array}{l}\text { No } \\
\text { Yes }\end{array}$ & $\begin{array}{l}\text { No } \\
\text { Yes }\end{array}$ & $\begin{array}{l}\text { Duodenal ulcer } \\
\text { Duodenal ulcer }\end{array}$ & $\begin{array}{l}\text { Duodenal ulcer } \\
\text { Irritable colon, } \\
\text { duodenal ulcer }\end{array}$ \\
\hline Yes & Yes & Yes & Yes & Barium meal and & Irritable colon, \\
\hline $\begin{array}{l}\text { No } \\
\text { Yes }\end{array}$ & $\begin{array}{l}\text { Yes } \\
\text { No }\end{array}$ & $\begin{array}{l}\text { No } \\
\text { Yes }\end{array}$ & $\begin{array}{l}\text { Yes } \\
\text { Yes }\end{array}$ & & $\begin{array}{l}\text { Irritable colon } \\
\text { Irritable colon, }\end{array}$ \\
\hline No & Yes & Yes & Yes & & Irritable colon \\
\hline
\end{tabular}

families other members also have symptoms of abdominal pain (Apley, 1959; Stone and Barbero, 1970; Øster, 1972). There is evidence to suggest that the site of the condition is in the colon (Dimson, 1971; Kopel, Kim, and Barbero, 1967; Stone and Barbero, 1970), the autonomic innervation of which is altered with resulting increased motility (Kopel et al., 1967). The present investigation supports some of the above points, by throwing light upon certain aspects of the long-term facts about children with RAP.

In previous investigations about one-third of children with RAP, apparently unaffected by treatment with reassurance and explanation, had abdominal symptoms as adults (Apley, 1959; Apley and Hale, 1973; Dahl and Haahr, 1969). From our investigation it seems that about half the children with this disorder, treated with reassurance and explanation, will be likely to suffer from abdominal symptoms as adults, as opposed to between one-third and one-fourth of children without RAP. The present follow-up took place as late as 28 to 30 years after hospitalization of the patients, which may account for the difference between the present and previous studies as to the frequency of continued symptoms. Further, a number of our patients with symptoms in the adult stage had experienced a symptom-free period during adolescence.

The investigation does not explain why some

TABLE V

Abdominal pains in children of adults with and without abdominal symptoms

\begin{tabular}{l|c|c}
\hline & $\begin{array}{c}46 \text { Children of adults with } \\
\text { abdominal symptoms }\end{array}$ & $\begin{array}{c}70 \text { Children of adults without } \\
\text { abdominal symptoms }\end{array}$ \\
\hline $\begin{array}{l}\text { Abdominal pains present } \\
\text { Abdominal pains absent }\end{array}$ & 13 & 5 \\
\hline
\end{tabular}


children with RAP will have symptoms as adults and others not.

The majority of adults with continued abdominal discomfort had symptoms suggesting the diagnosis of irritable colon. This may support the assumption that RAP in children is a result of a colonic disturbance, but does not prove it. The frequency of presumed psychosomatic symptoms in these patients as compared with controls is in keeping with the findings of Apley (1959) and Apley and Hale (1973), and with the view that children with RAP are vulnerable to emotional tension.

Although about half the children with RAP will develop abdominal disorders as adults, their symptoms do not greatly affect their social life or their normal life. In Apley and Hale's study also only 2 out of 11 with continued abdominal pains had symptoms severe enough to restrict their normal activities.

We were surprised to find that the children of persons with a history of RAP during childhood apparently did not suffer from abdominal pain more frequently than children of persons without RAP during childhood. Conway (1951) found the opposite. We and others (Apley, 1959; Stone and Barbero, 1970; Øster, 1972) have shown that the children of adults with abdominal symptoms currently are likely to suffer from abdominal pains more frequently than the children of adults with no such symptoms. The present investigation thus emphasizes parental abdominal symptoms occurring currently as a significant factor in childhood abdominal pains.

The best form of therapy remains to be settled. Apparently, the conventional reassurance and explanation is not sufficient, but we do not know whether more intense psychiatric treatment might prevent some little bellyachers from growing up to become big bellyachers.

This work was made possible by a grant from 'Børnefonden ved professor Bent Andersen, Århus'.

\section{REFERENCES}

Apley, J. (1959). The Child with Abdominal Pains. Blackwell Scientific Publications, Oxford.

Apley, J., and Hale, B. (1973). Children with recurrent abdominal pain: how do they grow up ? British Medical fournal, 3, 7.

British Medical fournal. (1970). Leading article. Recurrent abdominal pain in children, 4, 66 .

Conway, D. J. (1951). A study of abdominal pain in childhood. Great Ormond Street fournal, $2,99$.

Dahl, L., and Haahr, J. (1969). Recidiverende mavesmerter barnealderen. Ugeskrift for Laeger, 131, 1509.

Dimson, S. B. (1971). Transit time related to clinical findings in children with recurrent abdominal pain. Pediatrics, 47, 666 .

Green, M. (1967). Diagnosis and treatment: psychogenic, recurrent, abdominal pain. Pediatrics, 40,84.

Kopel, F. B., Kim, I. C., and Barbero, G. J. (1967). Comparison of rectosigmoid motility in normal children, children with recurrent abdominal pain, and children with ulcerative colitis. Pediatrics, 39, 539.

Mac Keith, R., and O'Neill, D. (1951). Recurrent abdominal pain in children. Lancet, 2, 278.

Moro, E. (1913). Ueber rezidivierende Nabelkoliken bei älteren Kindern. Muenchener Medizinische Wochenschrift, 60, 2827.

Øster, J. (1972). Recurrent abdominal pain, headache and limb pains in children and adolescents. Pediatrics, 50, 429.

Papatheophilou, R., Jeavons, P. M., and Disney, M. E. (1972). Recurrent abdominal pain: a clinical and electroencephalographic study. Developmental Medicine and Child Neurology, 14, 31 .

Singh, M. V., Gupta, S., and Agrawall, H. C. (1972). Sociopsychological basis of abdominal pain in children. Indian fournal of Pediatrics, 39, 33.

Stone, R. T., and Barbero, G. J. (1970). Recurrent abdominal pain in childhood. Pediatrics, 45, 732.

Correspondence to Dr. M. Fjord Christensen, Department of Paediatrics, Herning Central Hospital, 7400 Herning, Denmark. 